\title{
Effects of Long-Term Exercise on Age-Related Hearing Loss in Mice
}

\author{
[CChul Han, ${ }^{1}$ Dalian Ding, ${ }^{6}$ Maria-Cecilia Lopez, ${ }^{2}$ Senthilvelan Manohar, ${ }^{6}$ Yanping Zhang, ${ }^{3}$ Mi-Jung Kim, ${ }^{1}$ \\ Hyo-Jin Park, ${ }^{1,5}$ Karessa White, ${ }^{1}$ Yong Hwan Kim, ${ }^{4}$-Paul Linser, ${ }^{5}$ Masaru Tanokura, ${ }^{7}$ Christiaan Leeuwenburgh, ${ }^{1}$ \\ 얼 \\ ${ }^{1}$ Department of Aging and Geriatric Research, ${ }^{2}$ Department of Molecular Genetics and Microbiology, ${ }^{3}$ Gene Expression and Genotyping, Interdisciplinary \\ Center for Biotechnology Research, and ${ }^{4}$ Department of Physiology and Functional Genomics, University of Florida, Gainesville, Florida 32610, ${ }^{5}$ Whitney \\ Laboratory, University of Florida, St. Augustine, Florida 32080, ${ }^{6}$ Center for Hearing and Deafness, State University of New York at Buffalo, Buffalo, New \\ York 14214, and 7 Department of Applied Biological Chemistry, University of Tokyo, Yayoi, Tokyo, 113, Japan
}

Regular physical exercise reduces the risk for obesity, cardiovascular diseases, and disability and is associated with longer lifespan expectancy (Taylor et al., 2004; Pahor et al., 2014; Anton et al., 2015; Arem et al., 2015). In contrast, decreased physical function is associated with hearing loss among older adults (Li et al., 2013; Chen et al., 2015). Here, we investigated the effects of long-term voluntary wheel running (WR) on age-related hearing loss (AHL) in CBA/CaJ mice, a well established model of AHL (Zheng et al., 1999). WR activity peaked at 6 months of age $(12,280 \mathrm{~m} / \mathrm{d})$ and gradually decreased over time. At 24 months of age, the average WR distance was $3987 \mathrm{~m} / \mathrm{d}$. Twenty-four-month-old runners had less cochlear hair cell and spiral ganglion neuron loss and better auditory brainstem response thresholds at the low and middle frequencies compared with age-matched, non-WR controls. Gene ontology (GO) enrichment analysis of inner ear tissues from 6-month-old controls and runners revealed that WR resulted in a marked enrichment for G0 gene sets associated with immune response, inflammatory response, vascular function, and apoptosis. In agreement with these results, there was reduced stria vascularis (SV) atrophy and reduced loss of capillaries in the SV of old runners versus old controls. Given that SV holds numerous capillaries that are essential for transporting oxygen and nutrients into the cochlea, our findings suggest that long-term exercise delays the progression of AHL by reducing age-related loss of strial capillaries associated with inflammation.

Key words: aging; exercise; hearing loss; stria vascularis

Significance Statement

Nearly two-thirds of adults aged 70 years or older develop significant age-related hearing loss (AHL), a condition that can lead to social isolation and major communication difficulties. AHL is also associated with decreased physical function among older adults. In the current study, we show that regular exercise slowed AHL and cochlear degeneration significantly in a well established murine model. Our data suggest that regular exercise delays the progression of AHL by reducing age-related loss of strial capillaries associated with inflammation.

\section{Introduction}

Age-related hearing loss (AHL) is prevalent in nearly two-thirds of adults aged 70 years or older (Lin et al., 2011a; Li et al., 2013;

Received Aug. 5, 2016; revised Sept. 9, 2016; accepted Sept. 15, 2016.

Author contributions: C.H., H.V.B., and S.S. designed research; C.H., D.D., M.-C.L., S.M.,Y.Z., M.-J.K., H.-J.P., K.W., Y.H.K., and P.L. performed research; P.L., M.T., C.L., and R.J.S. contributed unpublished reagents/analytic tools; C.H., D.D., M.-C.L., S.M., Y.Z., M.-J.K., H.-J.P., K.W., Y.H.K., H.V.B., R.J.S., and S.S. analyzed data; C.H., M.T., C.L., H.V.B., R.J.S., and S.S. wrote the paper.

This work was supported by the National Institute on Deafness and Communication Disorders-National Institutes of Health (NIH Grants R01 DC012552, R01 DC014437, and R03 DC011840 to S.S.), the American Federation for Aging Research (Grant 12388 to S.S.), the Claude D. Pepper Older Americans Independence Centers at the University of Florida (NIH National Institute on Aging Grant 1 P30 AG028740), and the Japan Society for the Promotion of Science (Grant-in-Aid for Scientific Research 23228003).

The authors declare no competing financial interests.
Chen et al., 2015). AHL is characterized by poor speech understanding particularly in noise, impaired temporal resolution (Ozmeral et al., 2016), and central auditory processing deficits (Yamasoba et al., 2013). Human AHL is likely a multifactorial condition involving the interaction of a multitude of factors including aging, exposure to noise and ototoxic chemicals, genetics, and epigenetic variables (Xiao et al., 2004; Yamasoba et al., 2013). The major sites of age-related cochlear pathology include inner hair cells (IHCs) and outer hair cells (OHCs), spiral ganglion

Correspondence should be addressed to Shinichi Someya, Department of Aging and Geriatric Research, University of Florida, 2004 Mowry Road, P.0. Box 112610, Gainesville, FL 32610. E-mail: someya@ufl.edu.

DOI:10.1523/JNEUROSCI.2493-16.2016

Copyright $\odot 2016$ the authors $\quad 0270-6474 / 16 / 3611308-12 \$ 15.00 / 0$ 
neurons (SGNs), and stria vascularis (SV) (Gates and Mills, 2005; Yamasoba et al., 2013). The IHCs are the sensory receptors that relay their electrical response to the central auditory system through the SGNs (Hudspeth, 1997). Postmitotic hair cells and SGNs are particularly susceptible to injury from a combination of noise exposure, ototoxic chemicals, and oxidative damage (Gates and Mills, 2005; Yamasoba et al., 2013). The blood vessels in the SV are essential for transporting oxygen and nutrients such as glucose into the cochlea (Gates and Mills, 2005; Yamasoba et al., 2013). Therefore, age-related degeneration of these cochlear cells results in hearing loss.

Schuknecht (1955) defined sensory (hair cell loss), neural (SGN loss), and strial (SV degeneration) types of AHL based on correlations between cochlear pathology and the audiogram. A number of studies have indicated that an age-related degeneration of the SV is the most prominent feature of AHL in animals and humans (Schuknecht et al., 1974; Gates and Mills, 2005; Yamasoba et al., 2013). Indeed, AHL is often associated with significant loss of strial capillaries in the lateral wall of the gerbil cochlea (Gratton and Schulte, 1995), suggesting that an agerelated decline in blood flow, oxygen, and nutrients to the cochlea could lead to SV degeneration.

In older adults, an age-related decline in mobility (the ability to walk without assistance) is a major risk factor for mortality (Pahor et al., 2014; Anton et al., 2015). Importantly, long-term physical activity prolongs mobility in the elderly (Pahor et al., 2014), whereas leisure-time physical activity lowers the risk of 13 types of cancers (Moore et al., 2016) and increases life expectancy (Arem et al., 2015). Consistent with human data, lifelong voluntary wheel running (WR) in animals reduces body weight and oxidative damage to the heart and increases the median lifespan significantly (Holloszy et al., 1985; Judge et al., 2005). Middle-age onset of voluntary WR also improves memory function and hippocampal neurogenesis (Marlatt et al., 2012). The question then becomes whether regular exercise can slow AHL. A number of epidemiological studies have suggested that physical activity is associated with hearing sensitivity (Loprinzi et al., 2012; Chen et al., 2014; Gispen et al., 2014; Loprinzi et al., 2014; Mikkola et al., 2015; Tomioka et al., 2015), whereas slower gait speed, a robust indicator of health status, is associated with hearing loss among older adults (Lin et al., 2011a; Li et al., 2013; Chen et al., 2015). However, there is currently no direct evidence that regular physical activity can slow AHL in laboratory animals or humans. The objective of the current study was to examine the effects of longterm voluntary WR on AHL in CBA/CaJ mice, a well established model of AHL (Zheng et al., 1999).

\section{Materials and Methods}

\section{Animals}

CBA/CaJ mice were purchased from The Jackson Laboratory (https:// www.jax.org/strain/000654). Experiments were performed in accordance with protocols approved by the University of Florida Institutional Animal Care and Use Committee. The CBA/CaJ mouse strain displays late-onset AHL by $18-20$ months of age and is a widely used model of AHL (Zheng et al., 1999; Noben-Trauth et al., 2003). Because it is well documented that regular physical exercise reduces the risk for a variety of age-associated conditions and increases life expectancy in both men and women (Taylor et al., 2004; Pahor et al., 2014; Arem et al., 2015), male littermates were used in the current study.

\section{Voluntary exercise}

Male mice were single housed in a cage with or without a running wheel (Coulbourn Instruments). Mice were randomly divided into 5 groups: 3-month-old non-WR (NWR) control (young control), 6-month-old
NWR control (6-month-old control), 6-month-old WR (young runner), 24-month-old NWR control (old control), and 24-month-old WR (old runner) at 14 weeks of age, and the average running distance per day in the WR mice was recorded daily until 24 months of age. Mice fed ad libitum tend to decrease their voluntary running activity after $8-10$ months of age (Judge et al., 2005). Because slight food restriction ( $8-10 \%$ calorie restriction) prevents this decline, both runners and controls were fed a diet (AIN-93M; BioServ) that had $8-10 \%$ fewer calories than the average ad libitum intake of age-matched CBA/CaJ mice. The schedule of feeding for the control diet is $\sim 4 \mathrm{~g}$ every day (for a total of $\sim 101 \mathrm{kcal} /$ week). This dietary regime was maintained until the mice reached 24 months of age, as described previously (Someya et al., 2010). The running activity in the WR group was recorded by the computer connected to the running wheels using the program provided (Clocklab; Coulbourn Instruments) and the number of revolutions was calculated using the provided module in the MATLAB program (The MathWorks) and converted to the running distance per day (meters/day).

\section{Body weight and tissue weight}

The body weight of the mice was measured every week from 3 months of age until 24 months of age. The weight of tissues (liver, heart, lung, kidney, quadriceps, and gastrocnemius) of the mice was measured at 3 and 24 months of age.

\section{Blood glucose}

Mice at 3 and 24 months of age were subjected to overnight fasting. Blood samples were then collected from the tail vein the following day. Serum glucose levels were measured using a blood glucose meter (Contour; Bayer Health Care)

\section{ABR hearing test}

Auditory brainstem responses (ABRs) were measured with a tone burst stimulus at $4,8,16,32,48$, and $64 \mathrm{kHz}$ using an $\mathrm{ABR}$ recording system (Tucker Davis Technologies) at 3 and 24 months of age as described previously (Someya et al., 2010). Mice were anesthetized with a mixture of xylazine hydrochloride $(10 \mathrm{mg} / \mathrm{kg}$, i.m.; Phoenix Urology of St. Joseph) and ketamine hydrochloride ( $40 \mathrm{mg} / \mathrm{kg}$, i.m.; Phoenix Urology of St. Joseph) and placed on a warm heating pad. Needle electrodes were placed subcutaneously at the vertex (noninverting or active), ipsilateral ear (reference), and contralateral ear (ground). At each frequency, the sound level was decreased in $10 \mathrm{~dB}$ steps from 90 to $10 \mathrm{~dB}$ SPL. A hearing threshold was defined as the lowest level that produced a noticeable ABR response. Five to 10 mice per group were used for ABR threshold assessments. After the ABR hearing measurements, tissues from the same mice were used to conduct blood and histopathological analyses.

\section{Cochlear histology}

Histological evaluation. After the ABR hearing measurements, the animals were killed by cervical dislocation and the temporal bone was excised from the head and divided into cochlear and vestibular parts (Someya et al., 2010). The cochlea was then excised, immersed in a fixative containing 4\% paraformaldehyde (Sigma-Aldrich) in PBS solution for $1 \mathrm{~d}$, decalcified in 10\% EDTA for 1 week, and embedded in paraffin. The paraffin-embedded specimens were sliced along the mid-modiolar axis into $5 \mu \mathrm{m}$ sections, mounted on silane-coated slides, stained with H\&E, and observed under a light microscope (Leica). Rosenthal's canal was divided into three regions: apical, middle, and basal, and the three regions were used for evaluation of cochlear histology. Four to five mice per group were used for histopathological assessment. In each mouse, every third modiolar section obtained from one cochlea was evaluated for a total of 10 sections. Tissues from the same animals were used for cochleograms, SGN counting, and SV thickness measurement.

Cochleogram. The number of IHC, first-row $\mathrm{OHCs}(\mathrm{OHC1})$, secondrow OHCs (OHC2), and third-row OHCs (OHC3) were counted over $0.24 \mathrm{~mm}$ intervals along the entire length of the cochlea under the microscope at $400 \times$ magnification as described previously (Ding et al., 1999; Ding et al., 2013). The counting results were then entered into a custom computer program designed to compute a cochleogram that shows the number of missing IHC and $\mathrm{OHC} 1-3$ as a function of percentage distance from the apex of the cochlea. A frequency-place map for 
mouse cochlea is shown on the abscissa in the figures as described previously (Müller et al., 2005; Ding et al., 2016).

SGN counting. SGNs were counted in the apical, middle, and basal regions of the cochlear sections using a $40 \times$ objective as described previously (Someya et al., 2010). Type I and type II neurons were not differentiated and cells were identified by the presence of a nucleus. The corresponding area of the Rosenthal canal was measured in digital photomicrographs of each canal profile. The perimeter of the canal was traced with a cursor using ImageJ software. The computer then calculated the area within the outline. SGN survival was calculated as the number of SGNs per square millimeter. Six to nine sections of the apical, middle, and basal turns were evaluated in one cochlea per mouse. Four to five mice per group were used for SGN counting.

\section{DNA microarray analysis}

Total RNA isolation. Labyrinth tissues including bony shell, cochlear lateral wall, cochlear basilar membrane, cochlear modiolus, utricle, saccule, and three semicircular canals were frozen in liquid nitrogen and then ground into a powder in a $1.5 \mathrm{ml}$ tube using a tissue homogenizer (Kimble-Chase). Total RNA from the powdered tissue was isolated using the NucleoSpin RNA II kit (Macherey-Nagel). Total RNA concentration was determined on a Qubit 2.0 Fluorometer (Thermo Fisher Scientific) and sample quality was assessed using a 2100 Bioanalyzer (Agilent Technologies).

Microarrays. All microarray sample preparation reactions were conducted using the GeneChip WT PLUS Reagent Kit (Affymetrix) and reactions were done following the manufacturer's protocols. Briefly, double-stranded cDNA was synthesized from $100 \mathrm{ng}$ of total RNA and then the antisense RNA was synthesized and amplified by in vitro transcription of the second-stranded cDNA template using T7 RNA polymerase. Fifteen micrograms of purified cRNA was used for sense-strand DNA synthesis by reverse transcription using second-cycle primers followed by RNAase $\mathrm{H}$ hydrolysis of the cRNA template, leaving singlestranded cDNA. After hydrolysis, the second-cycle, single-stranded cDNA was purified to remove enzymes, salts, and unincorporated dNTPs and then purified, single-stranded cDNA was fragmented, biotin labeled, and hybridized with rotation at $45^{\circ} \mathrm{C}$ for $16 \mathrm{~h}$ to the Affymetrix GeneChip Mouse Transcriptome Array. The arrays were washed and stained with the reagents supplied in GeneChip Hybridization Wash and Stain kit (Affymetrix) on an Affymetrix Fluidics Station 450 and scanned with a GeneChip 7G Scanner (Affymetrix).

GeneChip MTA_1.0 normalization and quality control analysis. Hybridization signal intensities were normalized using RMA as implemented in Partek Genomics Suite version 6.6. Hybridization signal intensities were found to be in a similar range on all GeneChips with a perfect match mean low intensity of 201 and a mean high intensity of 280 with a mean intensity of 236 . The GeneChip hybridized with one control sample had more variation in its perfect match probe cell intensities than the other GeneChips in the study, with a slightly greater proportion of dim probe cells; however, this GeneChip had a perfect match mean intensity of 230 close to the mean of all chips. Area under the curve analysis of the positive control and negative control probe sets resulted in a value of 0.9 for all GeneChips. Based on these quality control parameters, all GeneChips were used for higher-level analysis.

GO analysis. Apparent gene expression differences between control animals and WR animals were evaluated using a modified $t$ test using a random variance model as implemented in BRB Array Tools version 4.5. For this analysis, we used only the 28,677 probes present on the GeneChip that had ENTREZ IDs that are needed for subsequent gene set analyses. The threshold of determining significant gene sets was set at $p<$ 0.005 . GO analysis was conducted using the LS/KS permutation test algorithms and Efron-Tibshirani's gene set analysis maximum mean test as implemented in BRB array tools version 4.5 with a significance threshold of 0.005 . Again, a two-sample $t$ test was applied using the random variance model and $6416 \mathrm{GO}$ gene sets were investigated. Using the above three tests, 529 of the 5174 investigated Biological Process (BP) categories were found to be significant. The LS/KS permutation test identified 605, whereas the Efron-Tibshirani maxmean test identified 64 significant gene sets.
Data availability. The microarray dataset discussed herein has been deposited in the National Center for Biotechnology Information Gene Expression Omnibus and is accessible through GEO Series accession number GSE84682 (http://www.ncbi.nlm.nih.gov/geo/query/acc.cgi?acc=GSE84682).

\section{PCR Arrays}

The total RNA samples from the DNA microarray analysis were obtained from control and WR mice $(n=5)$. The cDNA was constructed from 150 ng of RNA used for the DNA microarray analysis using the RT2 firststrand cDNA kit (SABiosciences). The mRNA harvested from these groups was evaluated with the Cytokines and Chemokines $\mathrm{RT}^{2}$ Profiler array containing 84 genes involved in immune response and other inflammatory functions (Mouse Cytokines and Chemokines PAMM150ZA PCR Array; QIAGEN). PCR arrays had primers for housekeeping genes to facilitate normalization, a genomic DNA primer to detect genomic DNA contamination, three reverse transcription controls, and three positive PCR controls. Using the RT qPCR Master Mix (SABiosciences), real-time PCR was performed with a two-step cycling program with a hot start to activate the DNA polymerase at $95^{\circ} \mathrm{C}$ for $10 \mathrm{~min}$, followed by 40 cycles of amplification $\left(95^{\circ} \mathrm{C}\right.$ for $15 \mathrm{~s}, 60^{\circ} \mathrm{C}$ for $\left.1 \mathrm{~min}\right)$ using a Bio-Rad CFX Connect Real Time PCR System. The final cycle threshold (CT) values were obtained and $2^{(-\Delta \Delta C T)}$ was calculated by normalizing with the housekeeping gene $H s p 90 a b 1$ for each gene across the RT2 Profiler PCR arrays to determine fold change and regulation. Fold change $p$-values $<0.05$ were considered to be statistically significant. The $p$-values were calculated based on a Student's $t$ test of the replicate $2^{(-\Delta \Delta C T)}$ values for each gene in the control group versus the same gene in the WR groups.

\section{SV thickness measurements}

SV thickness was measured in $40 \times$ images of H\&E-stained mouse cochlear tissues. In the ImageJ program, the measurement was made by using a cursor to draw a line from the margin of the stria to the junction of the basal cells with the spiral ligament halfway between the attachment of Reissner's membrane and the spiral prominence (Han et al., 2016). Measurements were made at the basal, middle, and apical regions of the cochlea for each mouse and averages of each region were calculated for each mouse. Six to nine sections of the apical, middle, and basal turns were evaluated in one cochlea per mouse. Four to five mice per group were used for SV thickness measurements.

\section{Counting of capillaries}

To visualize capillaries in the SV, endomucin, a marker of endothelial cells, was stained on paraffin-embedded cochlear sections as described previously (Doebele et al., 2010; Zahr et al., 2016). Briefly, cochlear sections were rehydrated and subjected to antigen retrieval $(0.01 \mathrm{M} \mathrm{Na}$ citrate, $\mathrm{pH} 6.0$, for $30 \mathrm{~min}$ at $60^{\circ} \mathrm{C}$ ) and then incubated with rat anti-mouse endomucin antibodies (dilution 1:250; Santa Cruz Biotechnology). Binding of secondary antibodies (rat on mouse AP polymer; Biocare Medical) was detected with Vulcan Fast Red Chromogen Kit 2 (Biocare Medical). Sections were counterstained with hematoxylin QS (Vector Laboratories) and endomucin-positive capillaries in the SV in the apical, middle, and basal regions of the cochlear sections were counted using a $40 \times$ objective as described previously (Ohlemiller et al., 2009).

\section{Statistical analysis}

One-way ANOVA with post-Tukey multiple-comparisons test (GraphPad Prism version 4.03) was used to analyze the ABR thresholds, losses of SGN and strial capillaries, and thickness of SV. Two-way ANOVA with Bonferroni's post hoc test (GraphPad Prism version 4.03) was used to analyze the body weight, tissue weight, blood glucose, and cochleogram. Student's $t$ test was used to analyze gene expression in PCR arrays.

\section{Results}

\section{Effects of long-term voluntary WR on body weight and tissue weight}

To investigate whether long-term voluntary WR delays the progression of AHL, we conducted a WR study using CBA/CaJ mice. At 4 months of age, the average running distance was $4747 \mathrm{~m} / \mathrm{d}$ 
a

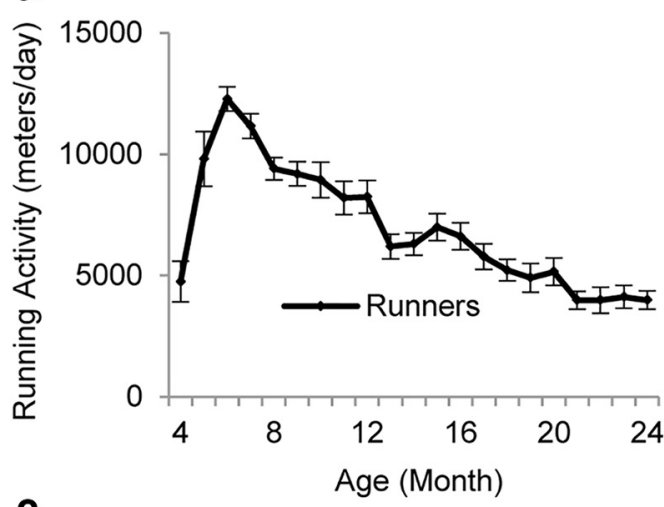

c

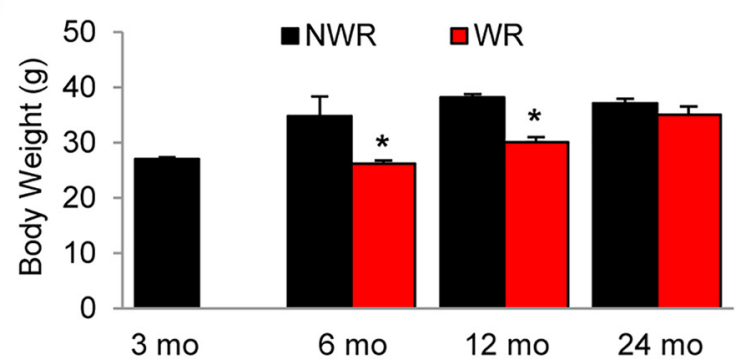

b

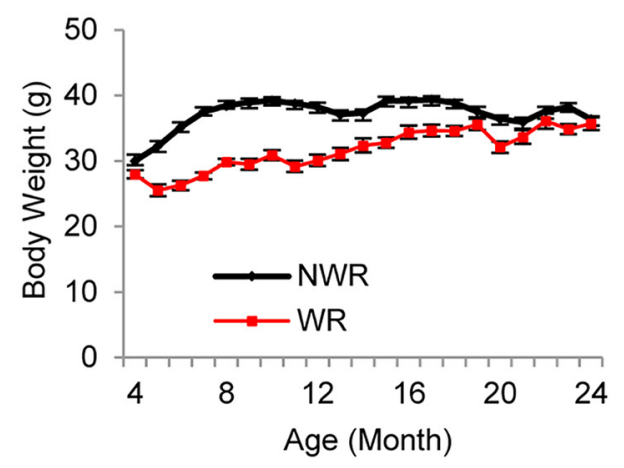

Figure 1. Effects of long-term voluntary WR on body weight. $\boldsymbol{a}$, Running distances $(\mathrm{m} / \mathrm{d})$ for the WR group were recorded and averaged between 4 and 24 months of age $(n=5-10)$. $\boldsymbol{b}$, Body weights of WR and NWR groups were recorded and averaged ( $n=5-10)$ between 4 and 24 months of age. c, Body weight of WR and NWR groups at $3,6,12$, and 24 months of age ( $n=5-10)$. Data are shown as means \pm SEM. ${ }^{*} p<0.001$ versus NWR.

Table 1. Running activity

\begin{tabular}{llrl}
\hline & \multicolumn{3}{l}{ Running activity $(\mathrm{m} / \mathrm{d})$} \\
\cline { 2 - 4 } Mouse ID & $6 \mathrm{mo}$ & $12 \mathrm{mo}$ & $24 \mathrm{mo}$ \\
\hline WR 1 & 11088 & 8904 & 4895 \\
WR2 & 14372 & 7713 & 3045 \\
WR3 & 11082 & 10781 & 6151 \\
WR 4 & 7441 & 3395 \\
WR5 & 10371 & 9794 & 3340 \\
WR 6 & 12928 & 6879 & 2112 \\
WR 7 & 10356 & 5606 & 3771 \\
WR 8 & 12281 & 11185 & 4436 \\
WR 9 & 13606 & 4752 & 4741 \\
Mean & 14124 & 8117 & 3987 \\
\hline
\end{tabular}

(Fig. 1a). Running activity peaked at 6 months of age $(12280 \mathrm{~m} / \mathrm{d})$ and gradually decreased over time. At 24 months of age, the average running distance was $3987 \mathrm{~m} / \mathrm{d}$. There were individual variations in running activity in the WR mice (Table 1). Over the 16 months, body weight in the WR group was less than the NWR control group. Average body weight of controls was 34.8, 38.2, and $37.2 \mathrm{~g}$ at 6,12 , and 24 months of age, respectively (Fig. 1b,c) versus $26.3,30.1$, and $35.0 \mathrm{~g}$, respectively, in the WR group. Body weight in the WR group was significantly less than controls at 6 and 12 months of age, but not at 24 months of age ( 6 months of age, $p<0.001, t=8.738 ; 12$ months of age, $p<0.001, t=7.788)$. The weight of the liver was significantly lower in the WR group compared with the NWR group at 24 months of age ( 6 months of age, $p<0.05, t=2.565 ; 24$ months of age, $p<0.05$ and $t=5.142$; Fig. $2 a$ ), whereas blood glucose was significantly less in the WR group versus the NWR group at 6 months of age ( 6 months of age, $p<0.001, t=6.455$; Fig. $2 g$ ). No differences were observed in other organs (Fig. 2b-f). Therefore, long-term WR reduced the body weight and blood glucose of runners significantly in early life; however, the differences between NWR and WR groups gradually diminished in later life. These results were in agreement with the running distance results: young adult mice run 12,000 $\mathrm{m} / \mathrm{d}$ on average; however, their running activity gradually declined in later life.

Effects of long-term WR on age-related losses of cochlear cells and hearing

The auditory function of CBA/CaJ mice is normal in early life, but declines gradually in later life (Zheng et al., 1999; Frisina and Zhu, 2010). To investigate whether long-term voluntary WR delays AHL, we conducted ABR hearing tests in control and WR CBA/ $\mathrm{CaJ}$ mice at 3 and 24 months of age. We first confirmed that ABR thresholds increased between 3 and 24 months of age at 4, 8, 16, 32,48 , and $64 \mathrm{kHz}$ in control mice. The age-related increases were statistically significant from 4 to $32 \mathrm{kHz}$ (Fig. $3 a-f$ ), indicating that these mice displayed AHL $\left(4 \mathrm{kHz}, p<0.001, F_{(2,22)}=18.70\right.$; $8 \mathrm{kHz}, p<0.001, F_{(2,22)}=38.81,16 \mathrm{kHz}, p<0.001, F_{(2,22)}=$ $41.95 ; 32 \mathrm{kHz}, p<0.01, F_{(2,22)}=8.75 ; 48 \mathrm{kHz}, p<0.01, F_{(2,22)}=$ $\left.7.05 ; 64 \mathrm{kHz}, p<0.05, F_{(2,22)}=6.28\right)$. However, we found that 24-month-old runners had significantly lower ABR thresholds at 8 and $16 \mathrm{kHz}$ frequencies compared with age-matched controls $\left(8 \mathrm{kHz}, p<0.001, F_{(2,22)}=38.81,16 \mathrm{kHz}, p<0.05, F_{(2,22)}=\right.$ 41.95; Fig. $3 b, c)$, indicating that long-term voluntary WR delayed the progression of AHL at the low and middle frequencies. There were no correlations between the total running distance and the ABR thresholds at 24 months of age (data not shown).

The major sites of age-related cochlear pathology typically include hair cells and SGNs in the cochlea (Gates and Mills, 2005; Yamasoba et al., 2013). To determine whether WR slows the progression of age-related loss of hair cells, mean cochleograms were prepared from 3-month-old controls, 24-month-old controls, and runners. At 3 months of age, there was little or no IHC loss or $\mathrm{OHC}$ loss in young controls (Fig. $4 a, b$ ). There was also little IHC loss in old controls or runners $(p<0.001, t=5.775$; 


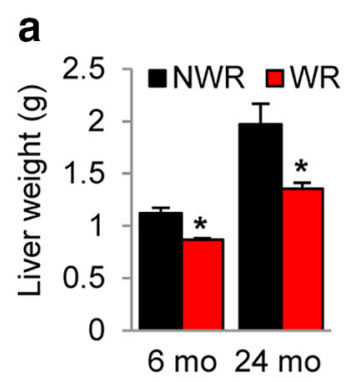

b

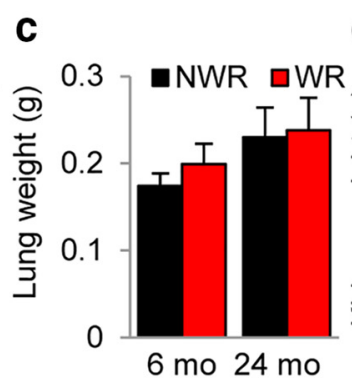

d
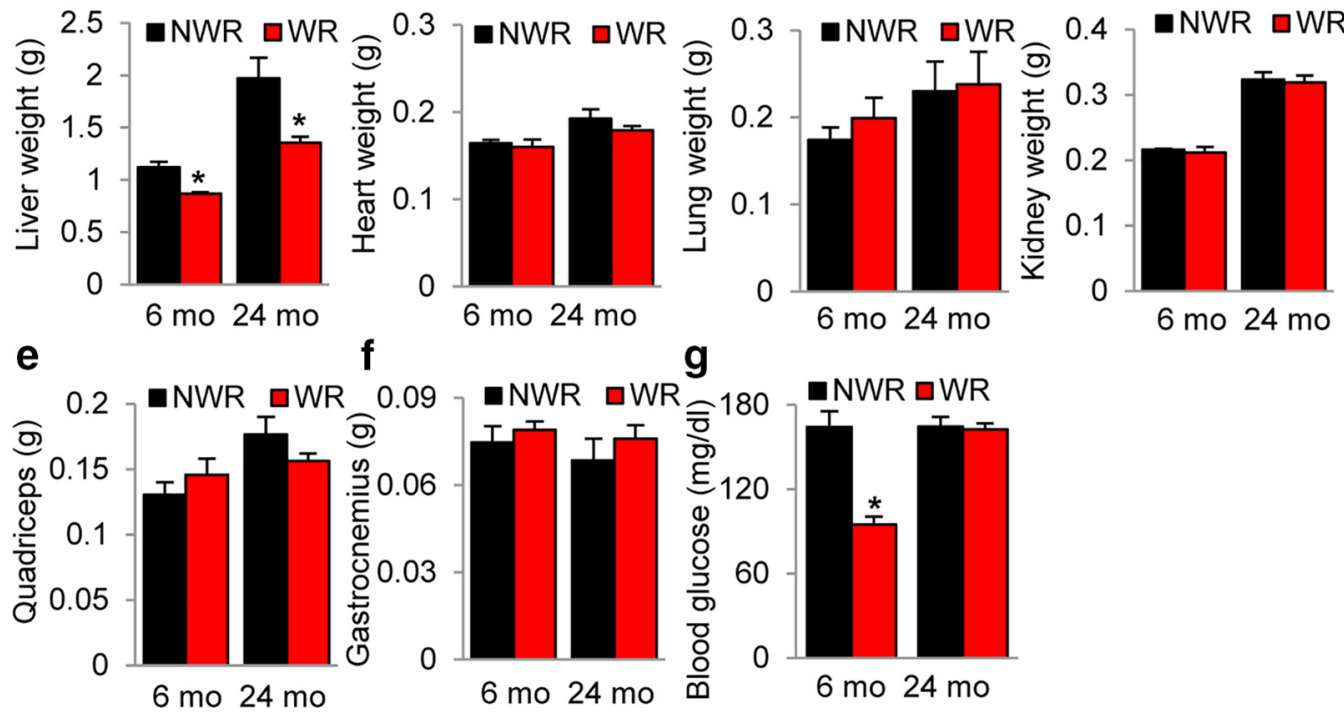

Figure 2. Effects of long-term WR on tissue weights and blood glucose. The blood glucose level $(\boldsymbol{g})$ and weights of liver $(\boldsymbol{a})$, heart $(\boldsymbol{b})$, lung $(\boldsymbol{c})$, kidney $(\boldsymbol{d})$, quadriceps (e), and gastrocnemius $(\boldsymbol{f})$ were measured in NWR and WR groups at 6 or 24 months of age $(n=5-10)$. Data are shown as means \pm SEM. ${ }^{*} p<0.05$ versus NWR.

Fig. 4a). In contrast, old control mice had severe OHC losses: $58-83 \%$ losses in the region $10-30 \%$ from the apex of the cochlea, corresponding to $\sim 6-11 \mathrm{kHz}(0-$ $10 \%, p<0.001, t=9.859 ; 10-20 \%, p<$ $0.001, t=8.912 ; 20-30 \%, p<0.001$, $t=6.897)$, whereas old runners showed moderate $\mathrm{OHC}$ losses of $14-61 \%$ in the region $10-30 \%$ from the apex (Fig. $4 b$ ). Old runners had significantly less $\mathrm{OHC}$ loss compared with age-matched NWR mice in the apical to middle regions of the cochlea $(0-10 \%$; $p<0.05, t=3.365 ; 10-$ $20 \%, p<0.05, t=4.073 ; 20-30 \%, p<$ $0.05, t=4.276$; Fig. $4 b$ ). We also counted the numbers of SGN in the apical, middle, and basal regions of the cochlea from the same groups (Fig. 5). At 3 months of age, there was no or minimal SGN loss in the apical, middle, or basal regions of the cochlea from young control mice (Fig. $5 j-l$ ). At 24 months of age, apical regions of the cochlea from control mice displayed severe losses of SGNs (63\% losses) compared with young controls $(p<0.001$; $F_{(2,11)}=36.47$; Fig. 5j). The basal regions of the cochlea from old control mice also displayed minor losses of SGNs (10\% losses) compared with young controls $\left(p<0.01, F_{(2,11)}=12.53\right.$; Fig. $\left.5 l\right)$. However, the mean SGN density of 24-oldmonth runners was significantly higher than that of age-matched control mice (apical, $p<0.001, F_{(2,11)}=36.47$; basal, $\left.p<0.05, F_{(2,11)}=12.53\right)$. Together, these physiological and histological analysis results show that long-term WR can reduce age-related losses of OHCs and SGNs in the apical regions of the cochlea and delay
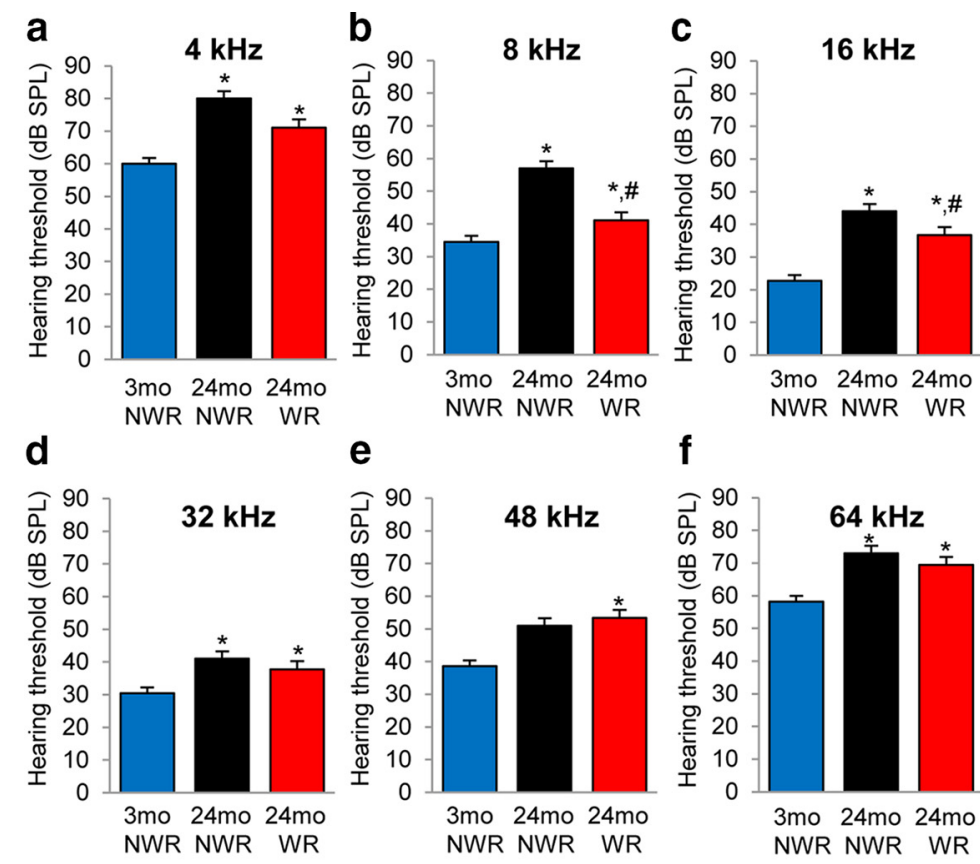

\section{e}

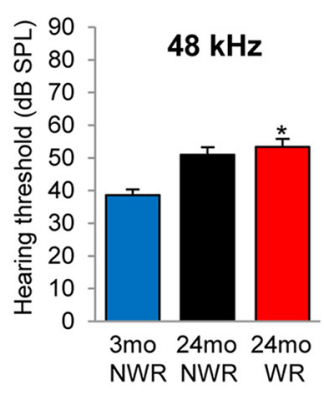

\section{f}

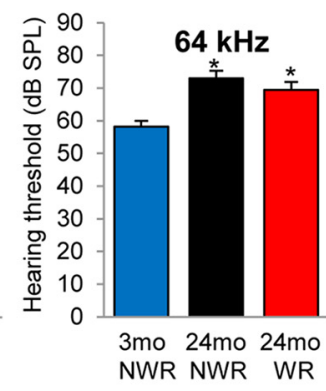

g

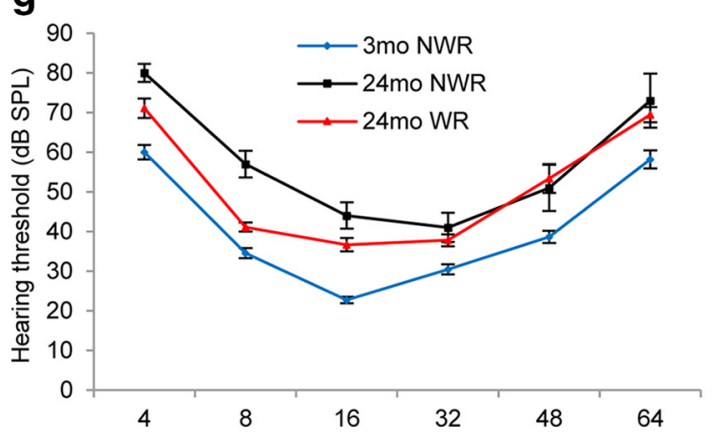

Figure 3. Effects of long-term WR on ABR (auditory brainstem response) hearing thresholds. $\boldsymbol{a}-\boldsymbol{f}$, ABR hearing thresholds from the 3-month-old NWR, 24-month-old NWR, and 24-month-old WR groups were measured at $4(\boldsymbol{a}), 8(\boldsymbol{b}), 16(\boldsymbol{c}), 32(\boldsymbol{d}), 48(\boldsymbol{e})$, and $64(\boldsymbol{f}) \mathrm{kHz}(n=5-10)$. Data are shown as means \pm SEM. ${ }^{*} p<0.05$ versus 3 -month-old NWR group. \#p $<0.05$ versus 24-month-old NWR group. $\boldsymbol{g}$, ABR hearing thresholds at all frequencies from the 3-month-old NWR, 24-month-old NWR, and 24-month-old WR groups. 
a

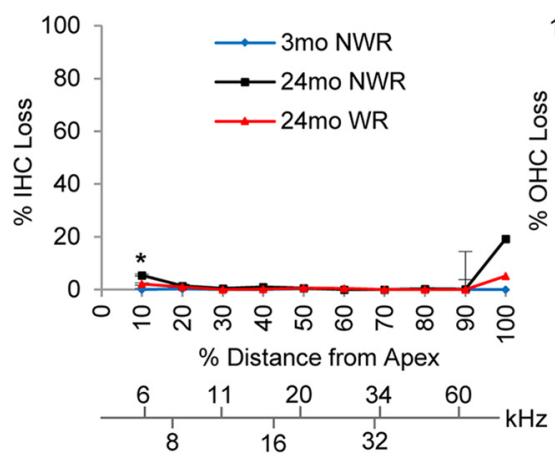

b

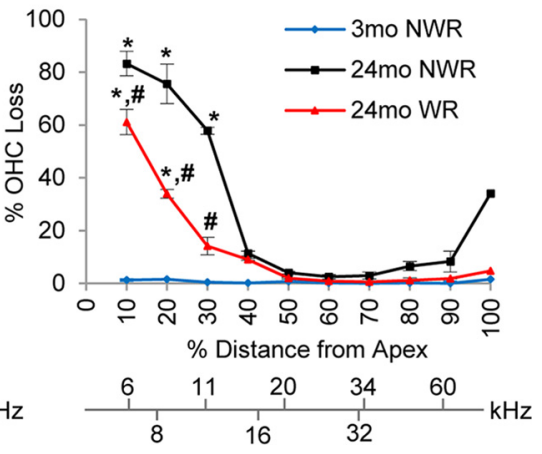

Figure 4. Effects of long-term WR on age-related hair cell loss. $\boldsymbol{a}, \boldsymbol{b}$, Cochleograms were recorded and averaged in the cochlear tissues of the young NWR (3-month-old), 24-month-old NWR, and WR groups $(n=5)$. The graphs show the quantification of cell loss in the IHCS (a) and $0 \mathrm{HCs}(\boldsymbol{b})$. Data are shown as means \pm SEM. ${ }^{*} p<0.05$ versus 3 -month-old NWR group; $\# p<0.05$ versus 24 -month-old NWR.

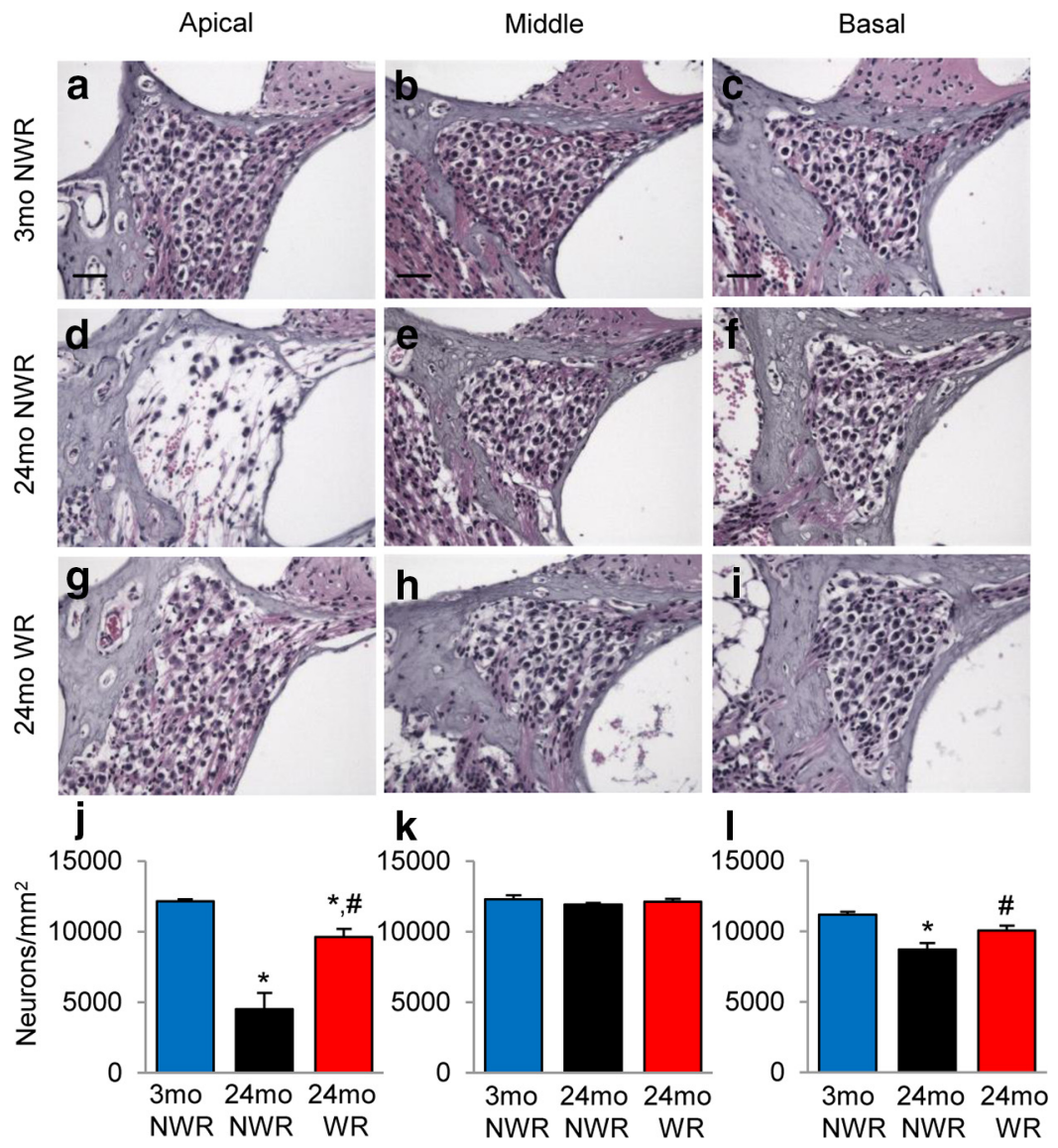

Figure 5. Effects of long-term WR on SGN loss. $\boldsymbol{a}-\boldsymbol{i}$, Number of SGNs in each different region (apical, middle, and basal) of cochlea tissue from young NWR (3-month-old; $\boldsymbol{a}$ - $\boldsymbol{c}$ ), old NWR (24-month-old, $\boldsymbol{d}$ - $\boldsymbol{f}$ ), and old WR (24-month-old, $\boldsymbol{g}$ - $\boldsymbol{i}$ ) groups ( $n=$ $4-5$ ) was counted and quantified $(j-I)$. Data are shown as means \pm SEM. ${ }^{*} p<0.05$ vs 3 -month-old NWR; $\# p<0.05$ versus 24-month-old NWR. Scale bar, $25 \mu \mathrm{m}$.

the progression of $\mathrm{AHL}$ in $\mathrm{CBA} / \mathrm{CaJ}$ mice at the low and middle frequencies.

Effects of WR on gene expression in the inner ear

To investigate the mechanisms by which voluntary WR reduces cochlear cell loss and delays AHL, we performed GO term analysis of inner ear tissues from 6-month-old controls and runners using Affymetrix GeneChip microarrays. We used 6-month-old mice for the gene expression analysis because our first WR study result indicates that voluntary $\mathrm{WR}$ activity peaked at $\sim 6$ months of age and reduced the body weight of runners significantly (Fig. 1a,b). We first confirmed that 6-month-old runners ran $11,909 \mathrm{~m} / \mathrm{d}$ and were significantly leaner compared with age-matched controls (23\% reduction; Fig. $6 a, b)$. Changes in gene expression levels were considered significant for $p$-values $\leq 0.005$. We used the 28,677 probes present on the GeneChip that had ENTREZ IDs, and 6416 GO gene sets were investigated. GO term analysis was conducted using the LS/KS permutation test algorithms and the Efron-Tibshirani's gene set analysis maximum mean test as implemented in BRB array tools version 4.5. Using this approach, 529 of the 5174 investigated $\mathrm{BP}$ categories were found to be significant; the 529 BP categories were displayed in a pie chart with seven subdivisions (Fig. 6c). We identified 108 of 529 BP categories $(20.4 \%)$ associated with "Immune System Process" induced by WR. We also identified $50 \mathrm{BP}$ categories (50/529) associated with "Response to Stimulus" and, among these, $\sim$ onethird or $32 \%(16 / 50)$ were associated with "Inflammatory Response" (Fig. $6 f$ ). Moreover, 60 BP categories (60/ 529) were associated with "Cellular Process" and, among these, 18.3\% (11/60) were associated with "Apoptotic Process" (Fig. 6e), consistent with the loss of IHCs, OHCs, and SGNs (Figs. 4, 5). We also identified 88 BP categories (88/ $529)$ associated with "Biological Regulation" and, among these, $14.8 \%(13 / 88)$ were associated with "Vasculature Development" or vascular function (Fig. $6 d)$. Collectively, GO gene sets that were most robustly induced by WR activity include those involved in immune response and inflammation, vascular function, and apoptosis.

Chronic inflammation is associated with low physical function in older adults (Brinkley et al., 2009; Hsu et al., 2009; Schaap et al., 2009), whereas low levels of inflammatory markers are associated with better survival in older adults (Giovannini et al., 2011). In laboratory animals, longterm WR reduces proinflammatory marker levels in the liver (Seo et al., 2006). Therefore, we reasoned that WR activity may reduce chronic inflammation within the cochlea. To test this hypothesis and to validate the GO term analysis results, we performed gene expression analysis of inner ear tissues from 6-month-old controls and runners using pathway-focused-PCR arrays containing 84 genes involved in cytokine and chemokine response. Seventy five percent ( 63 of 84 genes) of gene expression was detected: five 
a

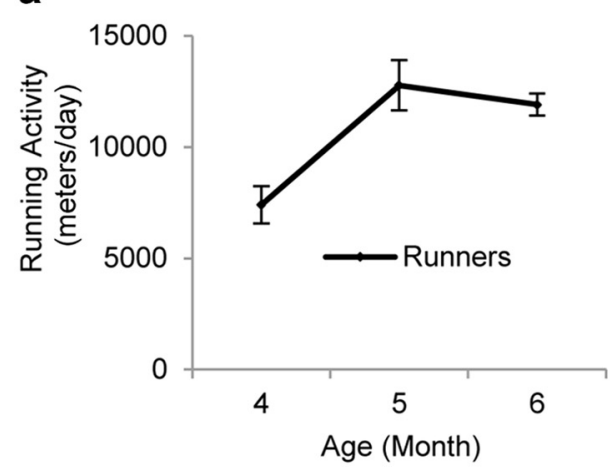

C

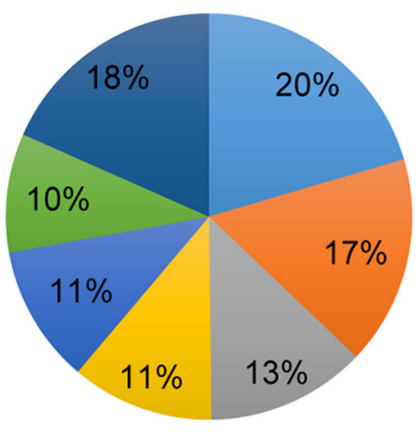

\section{Cellular process}

e

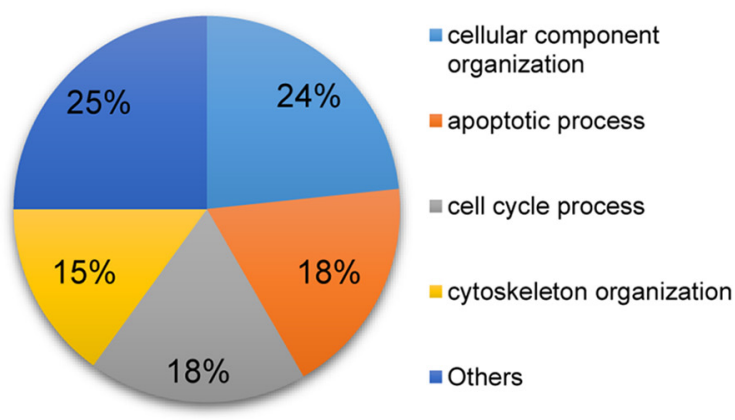

b

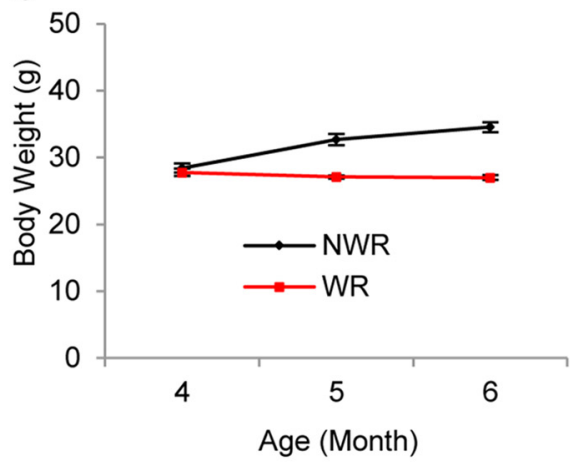

d Biological regulation

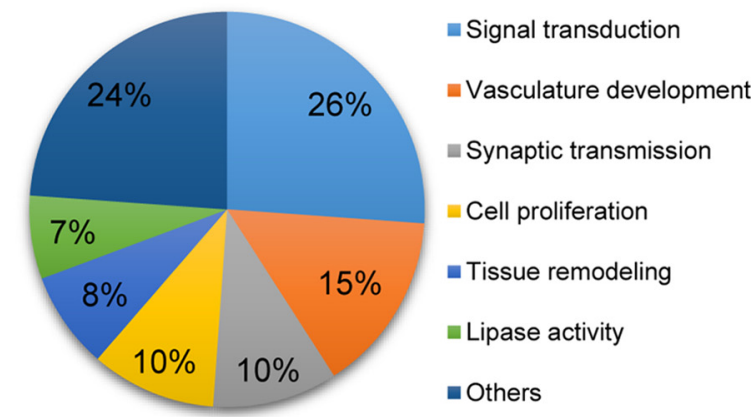

f

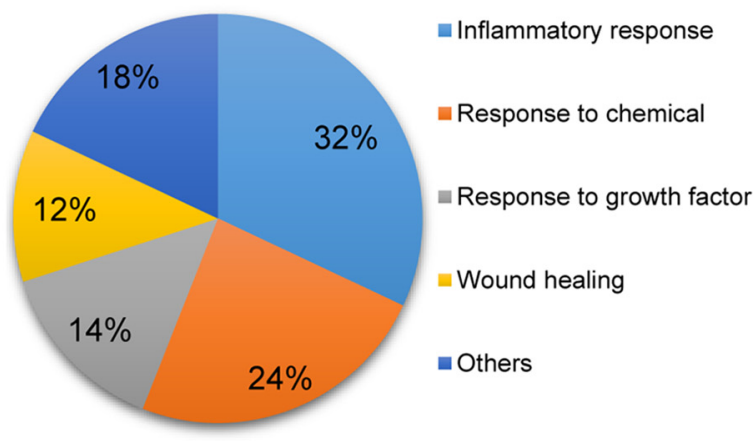

Figure 6. G0 term analysis. $\boldsymbol{a}$, Average running distance per day of 6-month-old WR group, $\boldsymbol{b}$, Body weight of NWR and WR groups between 3 and 6 months of age. Data are shown as means \pm SEM. c, 529 BP categories displayed in a pie chart with seven subdivisions. $\boldsymbol{d}, 88$ "Biological Regulation" categories displayed in a pie chart with seven subdivisions. $\boldsymbol{e}, 60$ "Cellular Process" categories displayed in a pie chart with five subdivisions. f, 50 "Response to Stimulus" categories displayed in a pie chart with five subdivisions.

genes in the inner ears of runners increased expression by more than $>75 \%$ (>1.7-fold upregulation), whereas 26 other genes decreased expression by $>50 \%$ ( $>0.75$ fold downregulation) relative to controls. Remarkably, WR downregulated $24 \%$ of the 63 genes detected or 15 genes involved in inflammation or inflammatory response significantly $(\mathrm{Ccl} 12$, Ppbp, Ccl3, Bmp4, Pf4, Il12a, Tnfrsf11b, Il15, Il18, Xcl1, Cxcl16, Cxcl12, Il7, Il4, and Tnf) in the inner ear (Fig. 7) (Jo et al., 2006; Cook, 1996; Ohmura et al., 2005; Allen et al., 2007; Lehrke et al., 2007; Srivastava et al., 2008; Dotan et al., 2010;

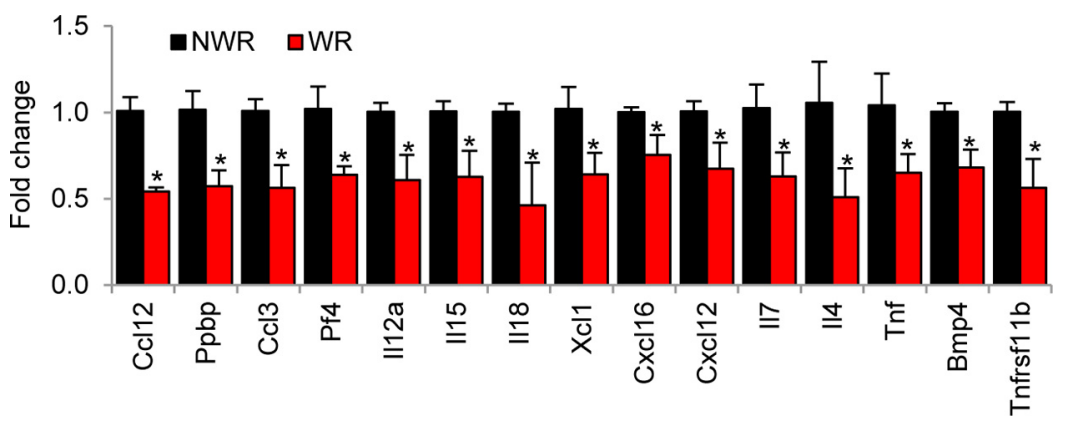

Figure 7. $\quad P C R$ array analysis. mRNA expression levels of 15 genes involved in inflammation were measured in the inner ears from the 6-month-old NWR (black bars) and WR (red bars) groups. Data are shown as means \pm SEM. ${ }^{*} p<0.05$ versus controls (NWR), Student's $t$ test. 


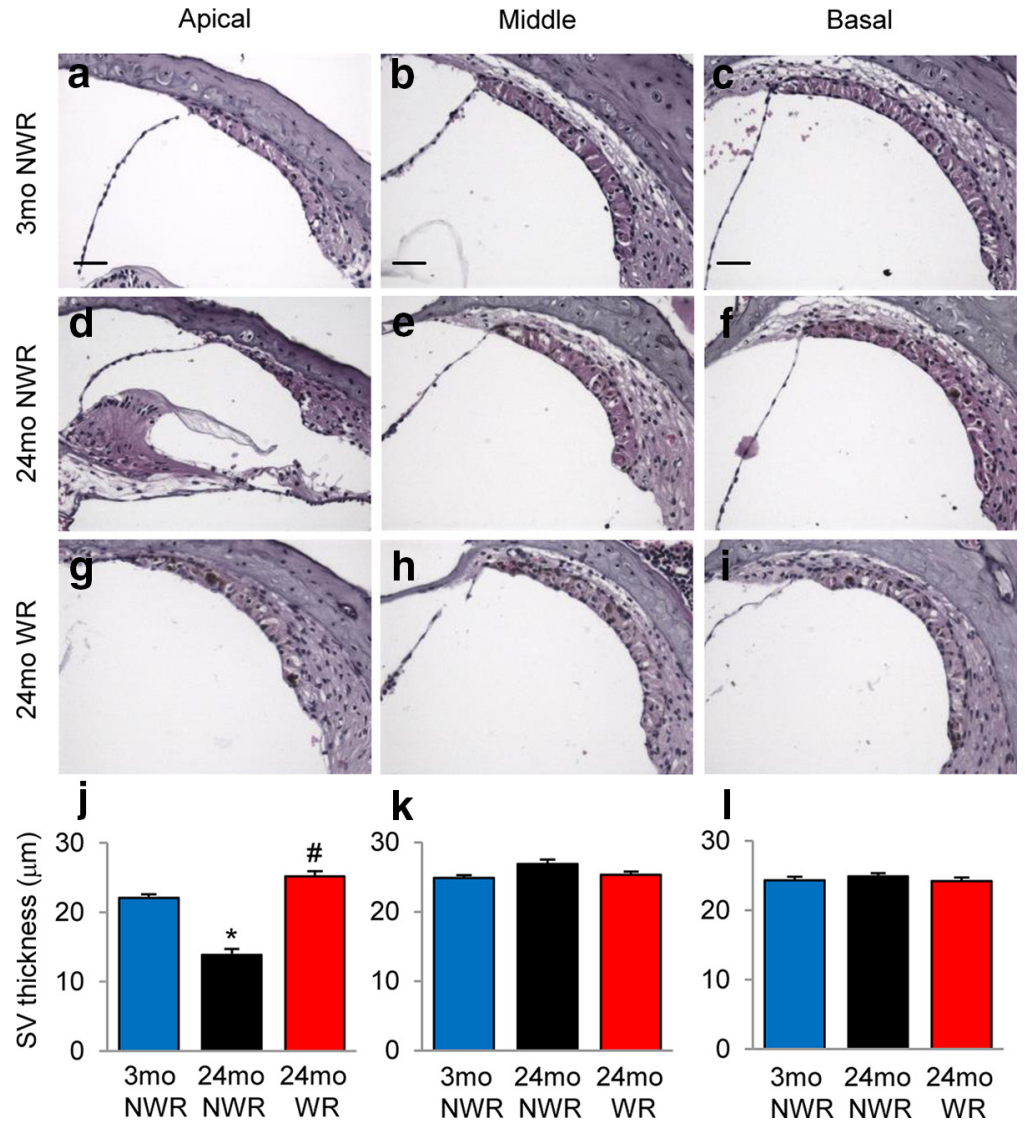

Figure 8. Effects of long-term WR on SV atrophy. $\boldsymbol{a}-\boldsymbol{i}$, Thickness of SV in each different region (apical, middle, and basal) of cochlea tissue from young NWR (3-month-old; $\boldsymbol{a}$ - $\boldsymbol{c}$ ), old NWR (24-month-old; $\boldsymbol{d}$ - $\boldsymbol{f}$ ), and old WR (24-month-old, $\boldsymbol{g}$ - $\boldsymbol{i}$ ) groups ( $n=$ 4-5) was measured and quantified $(\boldsymbol{j}-\boldsymbol{I})$. Data are shown as means \pm SEM. Scale bar, $25 \mu \mathrm{m} .{ }^{*} p<0.05$ versus 3 -month-old NWR; $\# p<0.05$ versus 24 -month-old NWR.

Hartgring et al., 2012; Kroczek and Henn, 2012; Pan et al., 2013; Ramesh et al., 2013). Collectively, the PCR array and GO term analysis results suggest that WR activity may reduce chronic inflammation in the inner ear.

\section{Effects of long-term WR on age-related SV atrophy and loss of strial capillaries}

Atrophy or degeneration of the SV in the cochlea is thought to be the most prominent feature of AHL in humans and laboratory animals (Schuknecht et al., 1974; Gates and Mills, 2005; Yamasoba et al., 2013). Because the GO term analysis results show that WR activity induces GO gene sets associated with vascular function (Fig. $6 d$ ), we measured the thickness of SV in the apical, middle, and basal regions of the cochlea from 3-month-old controls (Fig. $8 a-c$ ), 24-month-old controls (Fig. $8 d-f$ ), and runners (Fig. $8 g-i$ ). As expected, aging resulted in reduced SV thickness in the apical regions of the cochlea (33\% reduction) in 24 -monthold control mice, indicating strial atrophy $\left(p<0.05, F_{(2,11)}=\right.$ 8.529; Fig. 8j). Remarkably, there were no differences in the SV thickness in the apical regions of the cochlea between young controls and old runners. Moreover, the thickness of SV in the apical regions of the cochlea from 24-month-old runners was significantly higher than that of age-matched control mice $(p<0.01$, $F_{(2,11)}=8.529$; Fig. 8j). Aging also results in significant loss of capillaries in the SV (Gratton and Schulte, 1995) that is heavily vascularized and holds numerous capillaries (Gates and Mills, 2005; Yamasoba et al., 2013). Therefore, we investigated whether long-term exercise reduces age-associated loss of strial capillaries.
To visualize capillaries in the SV, cochlear sections were stained with the antibody specific to the endothelial marker endomucin. As expected, old control mice displayed significantly fewer capillaries in the apical regions of the cochlea compared with young controls ( $81 \%$ loss, $p<0.001$, $F_{(2,10)}=31.65$; Fig. 9j). There were no differences in the capillary numbers in the middle or basal regions of the cochlea between young controls and old controls (Fig. 9k,l); however, old runners displayed significantly more capillaries in the apical regions compared with agematched controls $\left(p<0.01, F_{(2,10)}=\right.$ 31.65), consistent with the SV thickness measurement results. Collectively, these histological analysis results show that long-term WR reduces age-related SV atrophy and losses of strial capillaries, supporting the GO term analysis results.

\section{Discussion}

One of the most preeminent features of human aging is dementia associated with memory loss and impaired thinking (Kalaria et al., 2008; Iadecola, 2013). Vascular dementia is the second most common type of dementia after Alzheimer's disease and caused by conditions that reduce blood flow to various regions of the brain (Kalaria et al., 2008; Gorelick et al., 2011; Iadecola, 2013). These conditions include strokes, ischemic strokes, thickening of the blood vessel walls, narrowing of the blood vessels, and wear and tear on the blood vessels. The SV contains numerous capillaries that are essential for transporting oxygen, nutrients, and water into the cochlea, so SV atrophy is one of the most prominent features of human AHL (Schuknecht et al., 1974; Gates and Mills, 2005; Frisina et al., 2006; Vasilyeva et al., 2009; Yamasoba et al., 2013). In agreement with this idea, old gerbils show reduced cochlear blood flow and a reduced number of strial capillaries compared with young gerbils (Prazma et al., 1990; Gratton and Schulte, 1995). In older adults, high-frequency hearing impairment was found to be related to high blood viscosity and increased red-cell rigidity (Browning et al., 1986), whereas an age-related loss of capillaries in the spiral ligament was observed in the cochlea (Johnsson and Hawkins, 1972). Importantly, hearing loss is associated with cognitive decline and dementia among older adults (Lin et al., 2011b, 2013; Gurgel et al., 2014; Deal et al., 2016). Consistent with these reports, our histological analysis results show that aging results in reduced SV thickness and fewer strial capillaries. Long-term exercise reduced age-related stria atrophy and loss of strial capillaries, whereas GO enrichment analysis revealed that WR enriched GO biological process gene sets associated with vascular function and apoptosis. Therefore, our findings suggest that regular exercise slows the development of AHL, likely by increasing cochlear blood flow or circulation. The SV also plays an essential role in generating proper endocochlear potential (EP), the main driving force for sound transduction (Wangemann, 2006; Ohlemiller, 2009). The EP is generated by the $\mathrm{K}^{+}$channel Kcnj10 located in the intermediate cells and 
$\mathrm{Na}^{+} / \mathrm{K}^{+}$-ATPase, ion exchanger NKCC, and KCNQ1/KCNE1 $\mathrm{K}^{+}$channels located in the marginal cells of the SV (Ding et al., 2014). Because the EP is generated by ion channels and pumps coupled to ATPases, cochlear stroke or ischemia can stop ion pump function instantaneously, reducing the EP and causing hearing loss. Therefore, our results suggest that regular exercise may slow the development of AHL by increasing oxygen transport and mitochondrial function in the SV, which in turn enhances ATP production.

A growing body of evidence indicates that elavated levels of inflammatory markers such as interleukin-6 (IL-6), tumor necrosis factor $\alpha$ (TNF- $\alpha)$, and $\mathrm{C}$-reactive protein (CRP) are associated with a decline in muscle mass and strength (Schaap et al., 2009), disability, and mortality among older adults (Harris et al., 1999; Vasan et al., 2003; Brinkley et al., 2009; Hsu et al., 2009). These results suggest that chronic, low-grade inflammation is a common mechanism for functional decline and ageassociated diseases in older adults (Franceschi and Campisi, 2014). In agreement with these reports, elevated levels of CRP, polymorphisms of TNF receptors, and genes involved in immunity were associated with the incidence of hearing impairment among older adults. (Dong et al., 2014; Nash et al., 2014; Uchida et al., 2014), whereas elevated markers of inflammatory status such as white blood cell count, neutrophil count, IL-6, and CRP were associated with degree of hearing loss in older people in the United Kingdom (Verschuur et al., 2012). In laboratory mice, an age-related elevation of the proinflammatory markers TNF- $\alpha$ and IL-1b was observed in the cochlea of SAMP8 mice, a mouse model of early-onset AHL (Menardo et al., 2012). The question then becomes what triggers chronic inflammation in the inner ear? One possibility is that inflammation may result from an age-related increase in cochlear coagulation (Wong and Ryan, 2015). Mitochondrial dysfunction due to multiple mild ischemia/strokes may also trigger chronic inflammation (Wong and Ryan, 2015). In the current study, we have demonstrated that WR results in a marked enrichment for GO biological processes associated with "Immune System Process" and "Inflammatory Response" and downregulates 15 genes involved in inflammation, including the TNF

receptor superfamily genes Tnf- $\alpha$ and Tnfrsf $11 b$ and the IL family genes $I l 12 a, I l 7$, and $I l 4$, in the inner ear. Taken together, chronic cochlear inflammation may play a key role in strial capillary loss and stria atrophy. Our results also suggest that regular exercise may reduce SV atrophy by reducing blood clots and/or improving oxygen transport in the cochlea. We note that, given that labyrinth tissues, which include both cochlea and vestibule, were used in the DNA microarray and PCR array analyses, long-term exercise may also reduce inflammation in the vestibular tissues.
Long-term voluntary WR significantly delayed the progression of AHL at the low $(8 \mathrm{kHz})$ and middle $(16 \mathrm{kHz})$ frequencies in CBA/CaJ mice, but not $4,32,48$, or $64 \mathrm{kHz}$. There are several potential explanations for the mild beneficial effects of voluntary exercise: First, long-term voluntary exercise significantly reduced body weight in early life. However, the difference in body weight between the NWR and WR groups gradually diminished in later life. This could be explained by the fact that running activity peaked at 6 months of age $(12,000 \mathrm{~m} / \mathrm{d})$ and gradually decreased over time. Another possibility is that long-term vigorous exercise (e.g., $\sim 12,000 \mathrm{~m} / \mathrm{d}$ for 2 years) may be required for slowing AHL in mice. Given that caloric restriction reduces body weight significantly, extends lifespan, and delays a variety of age-associated diseases, including AHL (Sohal and Weindruch, 1996; Colman et al., 2009; Someya et al., 2010), staying lean throughout the lifespan may also be essential for slowing AHL in mice. We speculate that, if the runners were forced to run $12,000 \mathrm{~m} / \mathrm{d}$ on average until 24 months of age as opposed to voluntary running, the older runners might have maintained better hearing at all of the frequencies measured. AHL generally affects the high-frequency and basal part of the cochleae first and/or more profoundly in humans (Gates and Mills, 2005; Yamasoba et al., 2013). In the current study, long-term voluntary WR reduced $\mathrm{OHC}$ loss in the apical to middle regions of the cochlea and delayed the progression of AHL at the low and middle frequencies in CBA/CaJ mice. Previous studies have shown that $\mathrm{CBA} / \mathrm{CaJ}$ mice lose hair cells in the apical region of the cochlea and lose hearing at low frequen- 
cies more profoundly with age (Spongr et al., 1997; Ding et al., 2001; Hequembourg and Liberman, 2001). Therefore, one potential explanation is that long-term exercise may slow the development of AHL by reducing age-related hair cell damage in the apical region of the cochlea in $\mathrm{CBA} / \mathrm{CaJ}$ mice.

In summary, AHL is likely a multifactorial condition involving the interaction of a multitude of factors including aging, exposure to noise and ototoxic chemicals, genetics, and epigenetic variables such as exercise (Yamasoba et al., 2013). Our study demonstrates that long-term voluntary WR significantly delays the progression of AHL in a well established mouse model of AHL. Further studies are needed to confirm our findings in humans and to determine whether more robust effects could be achieved in laboratory animals forced to maintain a high level of running throughout the lifespan.

\section{References}

Allen SJ, Crown SE, Handel TM (2007) Chemokine: receptor structure, interactions, and antagonism. Annu Rev Immunol 25:787-820. CrossRef Medline

Anton SD, et al. (2015) Successful aging: Advancing the science of physical independence in older adults. Ageing Res Rev 24:304-327. CrossRef Medline

Arem H, Moore SC, Patel A, Hartge P, Berrington de Gonzalez A, Visvanathan K, Campbell PT, Freedman M, Weiderpass E, Adami HO, Linet MS, Lee IM, Matthews CE (2015) Leisure time physical activity and mortality: a detailed pooled analysis of the dose-response relationship. JAMA Intern Med 175:959-967. CrossRef Medline

Brinkley TE, Leng X, Miller ME, Kitzman DW, Pahor M, Berry MJ, Marsh AP, Kritchevsky SB, Nicklas BJ (2009) Chronic inflammation is associated with low physical function in older adults across multiple comorbidities. J Gerontol A Biol Sci Med Sci 64:455-461. CrossRef Medline

Browning GG, Gatehouse S, Lowe GD (1986) Blood viscosity as a factor in sensorineural hearing impairment. Lancet 1:121-123. Medline

Chen DS, Genther DJ, Betz J, Lin FR (2014) Association between hearing impairment and self-reported difficulty in physical functioning. J Am Geriatr Soc 62:850-856. CrossRef Medline

Chen DS, Betz J, Yaffe K, Ayonayon HN, Kritchevsky S, Martin KR, Harris TB, Purchase-Helzner E, Satterfield S, Xue QL, Pratt S, Simonsick EM, Lin FR; Health ABC Study (2015) Association of hearing impairment with declines in physical functioning and the risk of disability in older adults. J Gerontol A Biol Sci Med Sci 70:654-661. CrossRef Medline

Colman RJ, Anderson RM, Johnson SC, Kastman EK, Kosmatka KJ, Beasley TM, Allison DB, Cruzen C, Simmons HA, Kemnitz JW, Weindruch R (2009) Caloric restriction delays disease onset and mortality in rhesus monkeys. Science 325:201-204. CrossRef Medline

Cook DN (1996) The role of MIP-1 alpha in inflammation and hematopoiesis. J Leukoc Biol 59:61-66. Medline

Deal JA, Betz J, Yaffe K, Harris T, Purchase-Helzner E, Satterfield S, Pratt S, Govil N, Simonsick EM, Lin FR; Health ABC Study Group (2016) Hearing impairment and incident dementia and cognitive decline in older adults: the health ABC study. J Gerontol A Biol Sci Med Sci. In press. CrossRef Medline

Ding B, Frisina RD, Zhu X, Sakai Y, Sokolowski B, Walton JP (2014) Direct control of $\mathrm{Na}(+)-\mathrm{K}(+)-2 \mathrm{Cl}(-)$-cotransport protein (NKCC1) expression with aldosterone. Am J Physiol Cell Physiol 306:C66-C75. CrossRef Medline

Ding D, Li M, Zheng X, Wang J, Salvi RJ (1999) Cochleogram for assessing hair cells and efferent fibers in carboplatin-treated ear. Lin Chuang Er Bi Yan Hou Ke Za Zhi 13:510-512. Medline

Ding D, McFadden SL, Salvi RJ (2001) Cochlear hair cell densities and inner ear staining techniques. In: Handbook of mouse auditory research from behavior to molecular biology (Willott JF, ed), pp 189-204. Boca Raton, FL: CRC.

Ding D, Qi W, Yu D, Jiang H, Han C, Kim MJ, Katsuno K, Hsieh YH, Miyakawa T, Salvi R, Tanokura M, Someya S (2013) Addition of exogenous NAD + prevents mefloquine-induced neuroaxonal and hair cell degeneration through reduction of caspase-3-mediated apoptosis in cochlear organotypic cultures. PLoS One 8:e79817. CrossRef Medline

Ding D, Jiang H, Chen GD, Longo-Guess C, Muthaiah VP, Tian C, Sheppard
A, Salvi R, Johnson KR (2016) N-acetyl-cysteine prevents age-related hearing loss and the progressive loss of inner hair cells in $\gamma$-glutamyl transferase 1 deficient mice. Aging (Albany NY) 8:730-750. CrossRef Medline

Doebele C, Bonauer A, Fischer A, Scholz A, Reiss Y, Urbich C, Hofmann WK, Zeiher AM, Dimmeler S (2010) Members of the microRNA-17-92 cluster exhibit a cell-intrinsic antiangiogenic function in endothelial cells. Blood 115:4944-4950. CrossRef Medline

Dong Y, Li M, Liu P, Song H, Zhao Y, Shi J (2014) Genes involved in immunity and apoptosis are associated with human presbycusis based on microarray analysis. Acta Otolaryngol 134:601-608. CrossRef Medline

Dotan I, Werner L, Vigodman S, Weiss S, Brazowski E, Maharshak N, Chen O, Tulchinsky H, Halpern Z, Guzner-Gur H (2010) CXCL12 is a constitutive and inflammatory chemokine in the intestinal immune system. Inflamm Bowel Dis 16:583-592. CrossRef Medline

Franceschi C, Campisi J (2014) Chronic inflammation (inflammaging) and its potential contribution to age-associated diseases. J Gerontol A Biol Sci Med Sci 69:S4-S9. CrossRef Medline

Frisina RD, Zhu X (2010) Auditory sensitivity and the outer hair cell system in the CBA mouse model of age-related hearing loss. Open Access Anim Physiol 2:9-16. Medline

Frisina ST, Mapes F, Kim S, Frisina DR, Frisina RD (2006) Characterization of hearing loss in aged type II diabetics. Hear Res 211:103-113. CrossRef Medline

Gates GA, Mills JH (2005) Presbycusis. Lancet 366:1111-1120. CrossRef Medline

Giovannini S, Onder G, Liperoti R, Russo A, Carter C, Capoluongo E, Pahor M, Bernabei R, Landi F (2011) Interleukin-6, C-reactive protein, and tumor necrosis factor-alpha as predictors of mortality in frail, community-living elderly individuals. J Am Geriatr Soc 59:1679-1685. CrossRef Medline

Gispen FE, Chen DS, Genther DJ, Lin FR (2014) Association between hearing impairment and lower levels of physical activity in older adults. J Am Geriatr Soc 62:1427-1433. CrossRef Medline

Gorelick PB et al.; American Heart Association Stroke Council, Council on Epidemiology and Prevention, Council on Cardiovascular Nursing, Council on Cardiovascular Radiology and Intervention, and Council on Cardiovascular Surgery and Anesthesia (2011) Vascular contributions to cognitive impairment and dementia: a statement for healthcare professionals from the American Heart Association/American Stroke Association. Stroke 42:2672-2713. CrossRef Medline

Gratton MA, Schulte BA (1995) Alterations in microvasculature are associated with atrophy of the stria vascularis in quiet-aged gerbils. Hear Res 82:44-52. CrossRef Medline

Gurgel RK, Ward PD, Schwartz S, Norton MC, Foster NL, Tschanz JT (2014) Relationship of hearing loss and dementia: a prospective, populationbased study. Otol Neurotol 35:775-781. CrossRef Medline

Han C, Linser P, Park HJ, Kim MJ, White K, Vann JM, Ding D, Prolla TA, Someya S (2016) Sirtl deficiency protects cochlear cells and delays the early onset of age-related hearing loss in C57BL/6 mice. Neurobiol Aging 43:58-71. CrossRef Medline

Harris TB, Ferrucci L, Tracy RP, Corti MC, Wacholder S, Ettinger WH Jr, Heimovitz H, Cohen HJ, Wallace R (1999) Associations of elevated interleukin-6 and C-reactive protein levels with mortality in the elderly. Am J Med 106:506-512. CrossRef Medline

Hartgring SA, Willis CR, Bijlsma JW, Lafeber FP, van Roon JA (2012) Interleukin-7-aggravated joint inflammation and tissue destruction in collagen-induced arthritis is associated with $\mathrm{T}$-cell and B-cell activation. Arthritis Res Ther 14:R137. CrossRef Medline

Hequembourg S, Liberman MC (2001) Spiral ligament pathology: a major aspect of age-related cochlear degeneration in C57BL/6 mice. J Assoc Res Otolaryngol 2:118-129. CrossRef Medline

Holloszy JO, Smith EK, Vining M, Adams S (1985) Effect of voluntary exercise on longevity of rats. J Appl Physiol 59:826-831. Medline

Hsu FC, Kritchevsky SB, Liu Y, Kanaya A, Newman AB, Perry SE, Visser M, Pahor M, Harris TB, Nicklas BJ; Health ABC Study (2009) Association between inflammatory components and physical function in the health, aging, and body composition study: a principal component analysis approach. J Gerontol A Biol Sci Med Sci 64:581-589. Medline

Hudspeth AJ (1997) How hearing happens. Neuron 19:947-950. CrossRef Medline 
Iadecola C (2013) The pathobiology of vascular dementia. Neuron 80:844866. CrossRef Medline

Jo H, Song H, Mowbray A (2006) Role of NADPH oxidases in disturbed flow- and BMP4- induced inflammation and atherosclerosis. Antioxid Redox Signal 8:1609-1619. CrossRef Medline

Johnsson LG, Hawkins JE Jr (1972) Strial atrophy in clinical and experimental deafness. Laryngoscope 82:1105-1125. CrossRef Medline

Judge S, Jang YM, Smith A, Selman C, Phillips T, Speakman JR, Hagen T, Leeuwenburgh C (2005) Exercise by lifelong voluntary wheel running reduces subsarcolemmal and interfibrillar mitochondrial hydrogen peroxide production in the heart. Am J Physiol Regul Integr Comp Physiol 289:R1564-R1572. CrossRef Medline

Kalaria RN, Maestre GE, Arizaga R, Friedland RP, Galasko D, Hall K, Luchsinger JA, Ogunniyi A, Perry EK, Potocnik F, Prince M, Stewart R, Wimo A, Zhang ZX, Antuono P; World Federation of Neurology Dementia Research Group (2008) World Federation of Neurology Dementia Research Group Alzheimer's disease and vascular dementia in developing countries: prevalence, management, and risk factors. Lancet Neurol 7:812-826. CrossRef Medline

Kroczek RA, Henn V (2012) The role of XCR1 and its ligand xcll in antigen cross-presentation by murine and human dendritic cells. Front Immunol 3:14. CrossRef Medline

Lehrke M, Millington SC, Lefterova M, Cumaranatunge RG, Szapary P, Wilensky R, Rader DJ, Lazar MA, Reilly MP (2007) CXCL16 is a marker of inflammation, atherosclerosis, and acute coronary syndromes in humans. J Am Coll Cardiol 49:442-449. CrossRef Medline

Li L, Simonsick EM, Ferrucci L, Lin FR (2013) Hearing loss and gait speed among older adults in the United States. Gait Posture 38:25-29. CrossRef Medline

Lin FR, Metter EJ, O’Brien RJ, Resnick SM, Zonderman AB, Ferrucci L (2011a) Hearing loss and incident dementia. Arch Neurol 68:214-220. CrossRef Medline

Lin FR, Thorpe R, Gordon-Salant S, Ferrucci L (2011b) Hearing loss prevalence and risk factors among older adults in the United States. J Gerontol A Biol Sci Med Sci 66:582-590. CrossRef Medline

Lin FR, Yaffe K, Xia J, Xue QL, Harris TB, Purchase-Helzner E, Satterfield S, Ayonayon HN, Ferrucci L, Simonsick EM; Health ABC Study Group (2013) Hearing loss and cognitive decline in older adults. JAMA Intern Med 173:293-299. CrossRef Medline

Loprinzi PD, Cardinal BJ, Gilham B (2012) Association between cardiorespiratory fitness and hearing sensitivity. Am J Audiol 21:33-40. CrossRef Medline

Loprinzi PD, Gilham B, Cardinal BJ (2014) Association between accelerometer-assessed physical activity and objectively measured hearing sensitivity among U.S. adults with diabetes. Res Q Exerc Sport 85:390397. CrossRef Medline

Marlatt MW, Potter MC, Lucassen PJ, van Praag H (2012) Running throughout middle-age improves memory function, hippocampal neurogenesis, and BDNF levels in female C57BL/6J mice. Dev Neurobiol 72:943-952. CrossRef Medline

Menardo J, Tang Y, Ladrech S, Lenoir M, Casas F, Michel C, Bourien J, Ruel J, Rebillard G, Maurice T, Puel JL, Wang J (2012) Oxidative stress, inflammation, and autophagic stress as the key mechanisms of premature age-related hearing loss in SAMP8 mouse Cochlea. Antioxid Redox Signal 16:263-274. CrossRef Medline

Mikkola TM, Polku H, Portegijs E, Rantakokko M, Rantanen T, Viljanen A (2015) Self-reported hearing Status is associated with lower limb physical performance, perceived mobility, and activities of daily living in older community-dwelling men and women. J Am Geriatr Soc 63:1164-1169. CrossRef Medline

Moore SC et al. (2016) Association of leisure-time physical activity with risk of 26 types of cancer in 1.44 million adults. JAMA Intern Med 176:816825. CrossRef Medline

Müller M, von Hünerbein K, Hoidis S, Smolders JW (2005) A physiological place-frequency map of the cochlea in the CBA/J mouse. Hear Res 202: 63-73. CrossRef Medline

Nash SD, Cruickshanks KJ, Zhan W, Tsai MY, Klein R, Chappell R, Nieto FJ, Klein BE, Schubert CR, Dalton DS, Tweed TS (2014) Long-term assessment of systemic inflammation and the cumulative incidence of agerelated hearing impairment in the epidemiology of hearing loss study. J Gerontol A Biol Sci Med Sci 69:207-214. CrossRef Medline

Noben-Trauth K, Zheng QY, Johnson KR (2003) Association of cadherin 23 with polygenic inheritance and genetic modification of sensorineural hearing loss. Nat Genet 35:21-23. CrossRef Medline

Ohlemiller KK (2009) Mechanisms and genes in human strial presbycusis from animal models. Brain Res 1277:70 - 83. CrossRef Medline

Ohlemiller KK, Rice ME, Lett JM, Gagnon PM (2009) Absence of strial melanin coincides with age-associated marginal cell loss and endocochlear potential decline. Hear Res 249:1-14. CrossRef Medline

Ohmura K, Nguyen LT, Locksley RM, Mathis D, Benoist C (2005) Interleukin- 4 can be a key positive regulator of inflammatory arthritis. Arthritis Rheum 52:1866-1875. CrossRef Medline

Ozmeral EJ, Eddins AC, Frisina DR Sr, Eddins DA (2016) Large crosssectional study of presbycusis reveals rapid progressive decline in auditory temporal acuity. Neurobiol Aging 43:72-78. CrossRef Medline

Pahor M, Guralnik JM, Ambrosius WT, Blair S, Bonds DE, Church TS, Espeland MA, Fielding RA, Gill TM, Groessl EJ, King AC, Kritchevsky SB, Manini TM, McDermott MM, Miller ME, Newman AB, Rejeski WJ, Sink KM, Williamson JD; LIFE study investigators (2014) Effect of structured physical activity on prevention of major mobility disability in older adults: the LIFE study randomized clinical trial. JAMA 311:2387-2396. CrossRef Medline

Pan W, Wu X, He Y, Hsuchou H, Huang EY, Mishra PK, Kastin AJ (2013) Brain interleukin-15 in neuroinflammation and behavior. Neurosci Biobehav Rev 37:184-192. CrossRef Medline

Prazma J, Carrasco VN, Butler B, Waters G, Anderson T, Pillsbury HC (1990) Cochlear microcirculation in young and old gerbils. Arch Otolaryngol Head Neck Surg 116:932-936. CrossRef Medline

Ramesh G, MacLean AG, Philipp MT (2013) Cytokines and chemokines at the crossroads of neuroinflammation, neurodegeneration, and neuropathic pain. Mediators Inflamm 2013:480739. CrossRef Medline

Schaap LA, Pluijm SM, Deeg DJ, Harris TB, Kritchevsky SB, Newman AB, Colbert LH, Pahor M, Rubin SM, Tylavsky FA, Visser M, Study HA (2009) Higher inflammatory marker levels in older persons: associations with 5-year change in muscle mass and muscle strength. J Gerontol A Biol Sci Med Sci 64:1183-1189. CrossRef Medline

Schuknecht HF (1955) Presbycusis. Laryngoscope 65:402-419. Medline

Schuknecht HF, Watanuki K, Takahashi T, Belal AA Jr, Kimura RS, Jones DD, Ota CY (1974) Atrophy of the stria vascularis, a common cause for hearing loss. Laryngoscope 84:1777-1821. CrossRef Medline

Seo AY, Hofer T, Sung B, Judge S, Chung HY, Leeuwenburgh C (2006) Hepatic oxidative stress during aging: effects of $8 \%$ long-term calorie restriction and lifelong exercise. Antioxid Redox Signal 8:529-538. CrossRef Medline

Sohal RS, Weindruch R (1996) Oxidative stress, caloric restriction, and aging. Science 273:59-63. CrossRef Medline

Someya S, Yu W, Hallows WC, Xu J, Vann JM, Leeuwenburgh C, Tanokura M, Denu JM, Prolla TA (2010) Sirt3 mediates reduction of oxidative damage and prevention of age-related hearing loss under caloric restriction. Cell 143:802-812. CrossRef Medline

Spongr VP, Flood DG, Frisina RD, Salvi RJ (1997) Quantitative measures of hair cell loss in CBA and C57BL/6 mice throughout their life spans. J Acoust Soc Am 101:3546-3553. CrossRef Medline

Srivastava K, Cockburn IA, Swaim A, Thompson LE, Tripathi A, Fletcher CA, Shirk EM, Sun H, Kowalska MA, Fox-Talbot K, Sullivan D, Zavala F, Morrell CN (2008) Platelet factor 4 mediates inflammation in experimental cerebral malaria. Cell Host Microbe 4:179-187. CrossRef Medline

Taylor RS, Brown A, Ebrahim S, Jolliffe J, Noorani H, Rees K, Skidmore B, Stone JA, Thompson DR, Oldridge N (2004) Exercise-based rehabilitation for patients with coronary heart disease: systematic review and metaanalysis of randomized controlled trials. Am J Med 116:682-692. CrossRef Medline

Tomioka K, Harano A, Hazaki K, Morikawa M, Iwamoto J, Saeki K, Okamoto N, Kurumatani N (2015) Walking speed is associated with self-perceived hearing handicap in high-functioning older adults: The Fujiwara-kyo study. Geriatr Gerontol Int 15:745-754. CrossRef Medline

Uchida Y, Sugiura S, Ueda H, Nakashima T, Ando F, Shimokata H (2014) The association between hearing impairment and polymorphisms of genes encoding inflammatory mediators in Japanese aged population. Immun Ageing 11:18. CrossRef Medline

Vasan RS, Sullivan LM, Roubenoff R, Dinarello CA, Harris T, Benjamin EJ, Sawyer DB, Levy D, Wilson PW, D'Agostino RB; Framingham Heart Study (2003) Inflammatory markers and risk of heart failure in elderly 
subjects without prior myocardial infarction: the Framingham Heart Study. Circulation 107:1486-1491. CrossRef Medline

Vasilyeva ON, Frisina ST, Zhu X, Walton JP, Frisina RD (2009) Interactions of hearing loss and diabetes mellitus in the middle age CBA/CaJ mouse model of presbycusis. Hear Res 249:44-53. CrossRef Medline

Verschuur CA, Dowell A, Syddall HE, Ntani G, Simmonds SJ, Baylis D, Gale CR, Walsh B, Cooper C, Lord JM, Sayer AA (2012) Markers of inflammatory status are associated with hearing threshold in older people: findings from the Hertfordshire Ageing Study. Age Ageing 41:92-97. CrossRef Medline

Wangemann P (2006) Supporting sensory transduction: cochlear fluid homeostasis and the endocochlear potential. J Physiol 576:11-21. CrossRef Medline

Wong AC, Ryan AF (2015) Mechanisms of sensorineural cell damage, death and survival in the cochlea. Front Aging Neurosci 7:58. CrossRef Medline
Xiao Y, Frisina R, Gordon A, Klebanov L, Yakovlev A (2004) Multivariate search for differentially expressed gene combinations. BMC Bioinformatics 5:164. CrossRef Medline

Yamasoba T, Lin FR, Someya S, Kashio A, Sakamoto T, Kondo K (2013) Current concepts in age-related hearing loss: epidemiology and mechanistic pathways. Hear Res 303:30-38. CrossRef Medline

Zahr A, Alcaide P, Yang J, Jones A, Gregory M, dela Paz NG, Patel-Hett S, Nevers T, Koirala A, Luscinskas FW, Saint-Geniez M, Ksander B, D'Amore PA, Argüeso P (2016) Endomucin prevents leukocyteendothelial cell adhesion and has a critical role under resting and inflammatory conditions. Nat Commun 7:10363. CrossRef Medline

Zheng QY, Johnson KR, Erway LC (1999) Assessment of hearing in 80 inbred strains of mice by ABR threshold analyses. Hear Res 130:94-107. CrossRef Medline 